\title{
Originals
}

\section{Early glomerular hyperfiltration and the development of late nephropathy in Type 1 (insulin-dependent) diabetes mellitus}

\author{
H.-H. Lervang ${ }^{1}$, S.Jensen ${ }^{1}$, J. Brøchner-Mortensen ${ }^{2}$ and J.Ditzel ${ }^{1}$ \\ ${ }^{1}$ Section of Endocrinology, Department of Medicine, and ${ }^{2}$ Department of Clinical Physiology, Aalborg Hospital, Denmark
}

\begin{abstract}
Summary. We performed a follow-up study of the glomerular function in a series of 29 Type 1 (insulin-dependent) diabetic patients who had been studied 18 years previously. Initial median duration of diabetes was 2 years (range $0-9$ ) and at follow-up 21 (17-27) years. At follow-up, 8 diabetic patients exhibited increased urinary albumin excretion rate $515(32-3234) \mu \mathrm{g} / \mathrm{min}$ with glomerular filtration rates significantly lower than 21 diabetic patients with normal urinary albumin excretion ( 85 vs $126 \mathrm{ml} / \mathrm{min} / 1.73 \mathrm{~m}^{2} ; p<0.01$ ). The patients with increased urinary albumin excretion rate also had higher arterial blood pressure $(145 / 90$ vs $120 / 80) \mathrm{mm} \mathrm{Hg} ; p<0.02)$ and increased frequency of pro-
\end{abstract}

liferative retinopathy ( 7 out of 8 vs 2 out of $21 ; p=0.0001$ ) as compared to the group with normal urinary albumin excretion. However, we found no association of increased urinary albumin excretion rate (incipient or overt nephropathy) to early glomerular hyperfiltration as median initial glomerular filtration rate was $142 \mathrm{ml} / \mathrm{min} / 1.73 \mathrm{~m}^{2}$ in the diabetic patients with increased urinary albumin excretion and $147 \mathrm{ml} / \mathrm{min} / 1.73 \mathrm{~m}^{2}$ in the patients with normal excretion rate $(p>0.05)$

Key words: Glomerular filtration rate, Type 1 (insulin-dependent) diabetes, microalbuminuria, diabetic nephropathy.
Increased glomerular filtration rate (GFR) is a well established feature of early uncomplicated Type 1 (insulin-dependent) diabetes [1-5]; changes in glomerular haemodynamics (increased transcapillary pressure and flow) are believed to be important for the development of diabetic glomerular injury [6-8]. Based on studies in animals with experimental diabetes it has been proposed that elevated GFR in early stages of the disease might predict the later development of nephropathy $[9$, 10]. This suggestion has recently been supported by findings in patients with Type 1 diabetes $[11,12]$. Because of the potential importance of being able to identify patients at risk for developing end-stage renal failure we decided to perform a follow-up study of the kidney function in a series of Type 1 diabetic patients who had been studied 18 years previously.

\section{Subjects and methods}

\section{Selection of patients}

As a result of growing interest in the late 1960s of identifying renal hyperfiltration in short-term diabetic patients, GFR was measured in 73 diabetic patients referred to our medical department from 1967 to 1969. Fifty-one of the 73 diabetic patients were considered to have
Type 1 diabetes. As part of a retrospective study 37 diabetic patients were selected for re-examination as they fulfilled the following criteria: (1) Males and females with Type 1 diabetes (2) Age at onset less than 40 years (3) Duration of diabetes at initial examination less than 10 years (4) None had clinical proteinuria $(>0.5 \mathrm{~g}$ per $24 \mathrm{~h}$ ) or diabetic retinopathy and (5) GFR and renal plasma flow (RPF) had concomitantly been measured at the initial examination. Eight out of the 37 selected patients could, however, for the following reasons not be re-examined. Four patients had died ( 2 of diabetic nephropathy, see Table 3), 2 could not be found through the central population registry, and 2 refused re-examination.

\section{Initial examination}

Initial and follow-up clinical features including some paraclinical data are shown in Tables 1, 2 and 3. Median age of the total 37 diabetic patients (21 males and 16 females) was 24 (range 11-39) years with a diabetes duration of $2(<1-9)$ years. Nine of the 37 patients had newly diagnosed diabetes at the initial examination; one was examined prior to insulin treatment, while the remaining 8 diabetic patients were investigated 8 [1-14] days after starting insulin treatment. Twenty-eight of the 37 diabetic patients had a duration of diabetes greater than 6 months. No effort was made to obtain a strict normalisation of the blood glucose. One newly-diagnosed diabetic patient and one with longer duration of the disease were mildly ketotic with serum bicarbonate $19.2 \mathrm{mmol} / 1$ (case no.10) and $18.0 \mathrm{mmol} / 1$ (case no.13) respectively. None of the patients had symptomatic hypoglycaemia during the examination. Besides having diabetes the patients were healthy and received no medication other than insulin. 
Table 1. Clinical features and some paraclinical data of the 29 re-examined diabetic patients

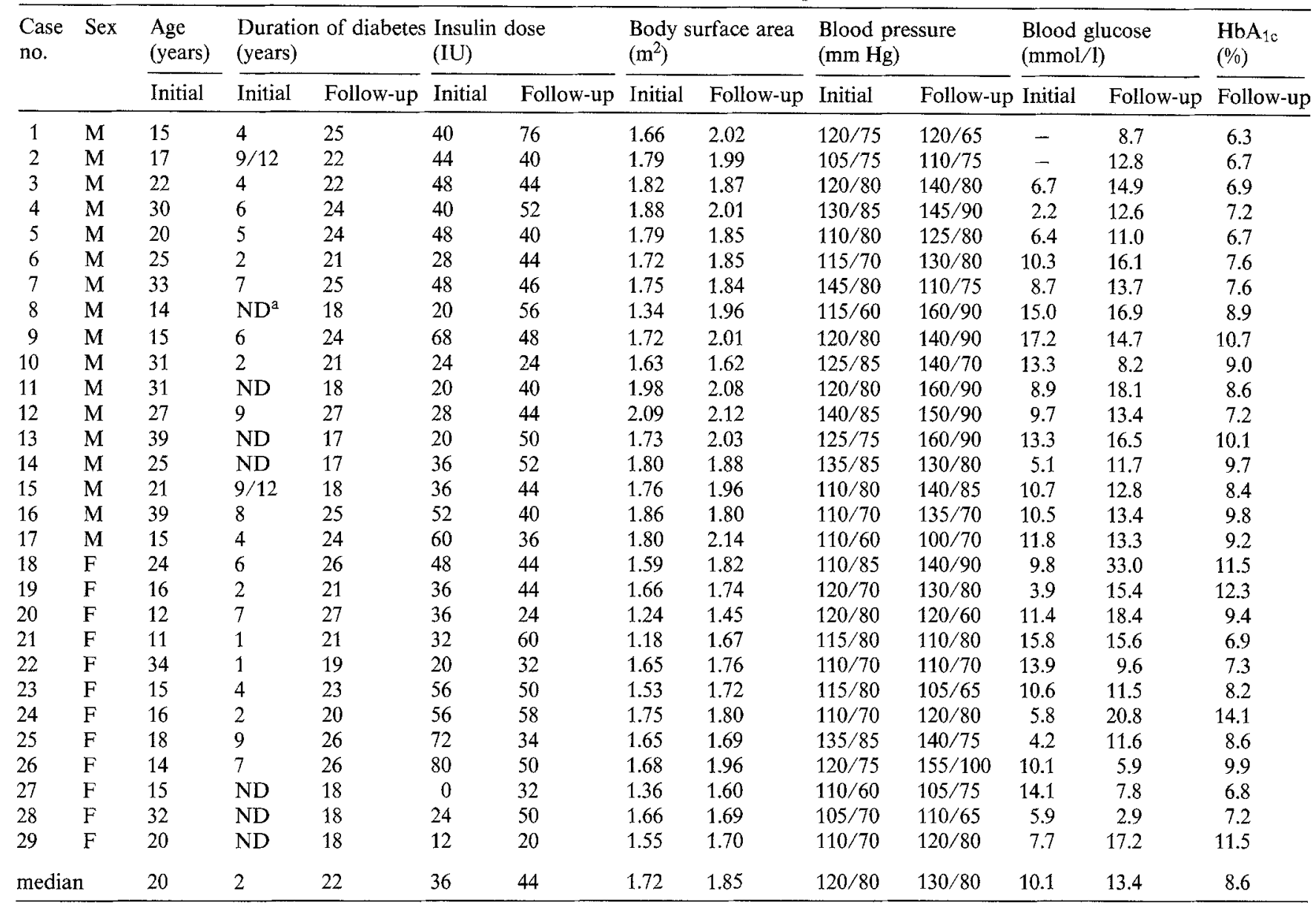

\footnotetext{
a Newly-diagnosed
}

All clearance tests were performed in the morning with the subjects in a supine position. Glomerular filtration rate was determined either by constant infusion of inulin (Laevosan Gesellschaft, Linz, Austria) or after a single injection of ${ }^{51} \mathrm{Chromium-EDTA}$ (Radiochemical Centre, Amersham, UK). After a priming dose of inulin (in 7 out of the 37 diabetic patients), a sustaining infusion was given allowing an equilibration period of not less than $30 \mathrm{~min}$. Three consecutive clearance tests were carried out in each patient. Urine was collected at the end of each test and blood specimens were drawn in the middle of each test. The ${ }^{51}$ Chromium-EDTA clearance (in 30 out of the 37 diabetic patients) was calculated from the plasma disappearance curve studied for at least $4 \mathrm{~h}$ after a single intravenous injection of $3.7 \mathrm{MBq}{ }^{51} \mathrm{Chromium}-\mathrm{EDTA}$ by taking venous blood samples every $5 \mathrm{~min}$ up to $30 \mathrm{~min}$ and thereafter every $30 \mathrm{~min}$. Previous comparison in this department of ${ }^{51} \mathrm{Chromium-EDTA}$ - and inulin clearances in 33 patients has shown good agreement with a regression line: ${ }^{51}$ Chromium-EDTA $=0.84 \times$ inulin $+12.27 \quad(r=0.97)$ [13]. For comparison the initial ${ }^{51}$ Chromium-EDTA clearance values were corrected according to this equation and the standard body surface area of $1.73 \mathrm{~m}^{2}$. RPF was measured either by the para-aminohippurate clearance method [14] or by ${ }^{125}$ I-hippuran [15]. Comparison in this laboratory of these two methods in 20 patients with normal and impaired renal function showed good correlation and therefore the ${ }^{125}$ I-hippuran clearance values were corrected according to the equation: para-aminohippurate $=1.132 \mathrm{x}^{125}$-I-hippuran $+14.24(r=0.99)[2]$.

A control group examined between 1967 and 1969 was included in the study. The data of the 29 control subjects ( 13 males and 16 females) are shown in Table 4. The median age was 30 [17-39] years. Suspected or known diagnoses during the hospital stay were previous epigastric pain in 9 subjects, irritable bowel syndrome in 2 , ce- phalgia in 1 , euthyroid goitre in 2 , neurosis in 14 and transient exanthema in 1 subject. The control group were otherwise healthy. Renal function tests were performed as described. GFR was measured by inulin clearance in 11 of the 29 control subjects or by ${ }^{51} \mathrm{Chromium-}$ EDTA clearance in the remaining 18 control subjects. Normal serum creatinine level in our laboratory was less than $140 \mu \mathrm{mol} / \mathrm{l}$ $(<1.3 \mathrm{mg} \%)$.

\section{Follow-up examination}

The 29 patients ( 17 males and 12 females) were re-examined after a median period of 18 [17-21] years following the initial examination. Median age was 38 [31-56] years and duration of diabetes 22 [17-27] years. GFR was measured after a single i.v. injection of $3.7 \mathrm{MBq}$ ${ }^{51}$ Chromium-EDTA (Radiochemical Centre, Amersham, UK.) starting at 09.00 hours [16]. Breakfast and the usual morning insulin dose were allowed. During the clearance study the patients were in a supine position and arterial blood pressure (phase I/V) was recorded with a standard mercury sphygmomanometer on three separate occasions during the clearance test by a trained nurse. Urinary albumin was measured ad modum (Mancini et al., 17) in 3 urine samples collected within one month following each clearance test. Increased urinary albumin excretion rate (UAE) was defined as an excretion rate greater than $20 \mu \mathrm{g} / \mathrm{min}$ in 2 out of 3 sterile timed overnight urine samples [18]. Serum creatinine was analysed using the Jaffe $^{\prime}$ reaction (normal value in our laboratory: $60-125 \mu \mathrm{mol} / \mathrm{l}$ ), serum $\beta_{2}$-microglobulin by a radioimmunoassay (Pharmacia $A B$, Uppsala, Sweden) (normal range: $70-210 \mathrm{nmol} / \mathrm{l}$ ) and glycosylated haemoglobin $\left(\mathrm{HbA}_{1 \mathrm{c}}\right.$ ) (normal range: $3.5-6.2 \%$ ) was measured by a chromatographic method [19]. 
Table 2. Paraclinical data on the 29 re-examined diabetic patients

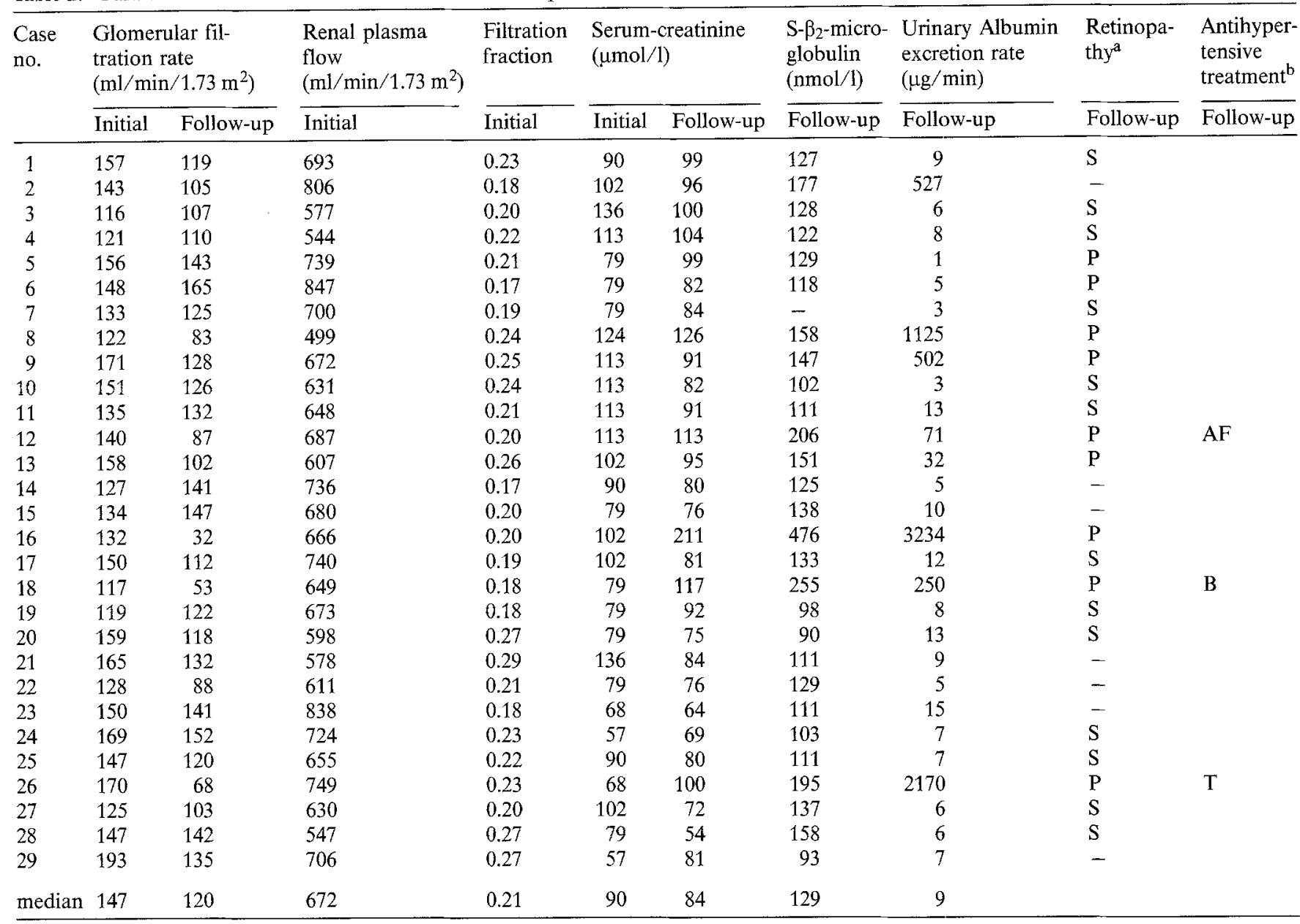

a Retinopathy was either of (S)simplex or (P)proliferative type; ${ }^{b} \mathrm{~A}$ : angiotensin converting enzyme inhibitor, B: selective $\beta$-blocking agent; F: furosemide; T: thiazide

\section{Statistical analysis}

Values are expressed as median with range. Test for significance was assessed non-parametrically using the Mann-Whitney test, the Fisher test or when appropriate the Spearman rank correlation coefficient (rho); $5 \%$ was chosen as the level of statistical significance.

\section{Results}

\section{Initial examination}

Initial examination of renal function in the 37 Type 1 diabetic patients (Tables 2 and 3) as compared to 29 healthy control subjects (Table 4) showed that both median GFR $\left[144(112-193) \mathrm{ml} / \mathrm{min} / 1.73 \mathrm{~m}^{2}\right.$ vs $\left.125(95-173) \mathrm{ml} / \mathrm{min} / 1.73 \mathrm{~m}^{2} ; p<0.002\right]$ and filtration fraction (defined as GFR divided with RPF) [0.21(0.16-0.29) vs $0.18(0.11-0.23) ; p<0.0001]$ were significantly increased in the diabetic patients. In the 8 patients not examined at follow-up the median GFR [141(112-171) vs $\left.147(116-193) \mathrm{ml} / \mathrm{min} / 1.73 \mathrm{~m}^{2}\right]$, RPF $\left[667(563-936)\right.$ vs $\left.672(499-847) \mathrm{ml} / \mathrm{min} / 1.73 \mathrm{~m}^{2}\right]$ and filtration fraction $[0.22(0.16-0.24)$ vs $0.21(0.17-0.29)]$ did not differ significantly from those of the remaining 29 diabetic patients. Nor was there found any significant difference between the median GFR [135(122-193) vs $\left.147(112-171) \mathrm{ml} / \mathrm{min} / 1.73 \mathrm{~m}^{2}\right]$, RPF $\left[630(499-736)\right.$ vs $\left.677(544-936) \mathrm{ml} / \mathrm{min} / 1.73 \mathrm{~m}^{2}\right]$ and filtration fraction $[0.22(0.17-0.27)$ vs $0.21(0.16-0.29)]$ in the 9 newly diagnosed Type 1 diabetic patients and the 28 patients with a duration longer than 6 months. In the two diabetic patients with serum bicarbonate below the lower normal limit initial GFR were $151 \mathrm{ml} / \mathrm{min} / 1.73 \mathrm{~m}^{2}$ (case no.10) and $158 \mathrm{ml} / \mathrm{min} /$ $1.73 \mathrm{~m}^{2}$ (case no.13). Initial GFR of the 2 patients dying from nephropathy (case nos. 32,37) were 144 and $112 \mathrm{ml} / \mathrm{min} / 1.73 \mathrm{~m}^{2}$ respectively. Duration of diabetes was not longer in the 8 patients not examined at follow-up as compared to the 29 diabetic patients participating in the follow-up examination. In both this group and in the 9 newly-diagnosed patients no significant difference was found between fasting blood glucose, insulin dose, body surface area or blood pressure as compared to the remaining diabetic patients. 
Table 3. Initial clinical features and some paraclinical data of the 8 diabetic patients not re-examined

\begin{tabular}{|c|c|c|c|c|c|c|c|c|c|c|c|}
\hline $\begin{array}{l}\text { Case } \\
\text { no. }\end{array}$ & Sex & $\begin{array}{l}\text { Age } \\
\text { (years) }\end{array}$ & $\begin{array}{l}\text { Duration of } \\
\text { diabetes } \\
\text { (years) }\end{array}$ & $\begin{array}{l}\text { Insulin } \\
\text { dose } \\
\text { (IU) }\end{array}$ & $\begin{array}{l}\text { Body sur- } \\
\text { face area } \\
\left(\mathrm{m}^{2}\right)\end{array}$ & $\begin{array}{l}\text { Blood } \\
\text { pressure } \\
(\mathrm{mm} \mathrm{Hg})\end{array}$ & $\begin{array}{l}\text { Blood- } \\
\text { glucose } \\
(\mathrm{mmol} / 1)\end{array}$ & $\begin{array}{l}\text { Serum- } \\
\text { creatinine } \\
(\mu \mathrm{mol} / 1)\end{array}$ & $\begin{array}{l}\text { Glomerular fil- } \\
\text { tration rate } \\
\left(\mathrm{ml} / \mathrm{min} / 1.73 \mathrm{~m}^{2}\right)\end{array}$ & $\begin{array}{l}\text { Renal plas- } \\
\text { ma flow } \\
\left(\mathrm{ml} / \mathrm{min} / 1.73 \mathrm{~m}^{2}\right)\end{array}$ & $\begin{array}{l}\text { Filtration } \\
\text { fraction }\end{array}$ \\
\hline 30 & $\mathbf{M}$ & 28 & 4 & 56 & 1.63 & $125 / 75$ & 8.2 & 124 & 147 & 936 & 0.16 \\
\hline $32^{b}$ & M & 32 & ND & 20 & 1.70 & $135 / 95$ & 9.2 & 136 & 144 & 678 & 0.21 \\
\hline $33^{\mathrm{c}}$ & M & 34 & 5 & 40 & 1.66 & $120 / 75$ & 10.7 & 79 & 138 & 615 & 0.22 \\
\hline 34 & $\mathrm{~F}$ & 37 & $6 / 12$ & 28 & 1.58 & $100 / 65$ & 13.4 & 68 & 171 & 725 & 0.24 \\
\hline $37^{b}$ & $\mathrm{~F}$ & 20 & 2 & 32 & 1.66 & $120 / 80$ & 4.9 & 90 & 112 & 561 & 0.20 \\
\hline \multicolumn{2}{|c|}{ median } & 31 & 3 & 32 & 1.65 & $120 / 75$ & 9.1 & 85 & 141 & 667 & 0.22 \\
\hline
\end{tabular}

${ }^{a}$ Newly-diagnosed. Died from ${ }^{b}$ diabetic nephropathy; from ${ }^{c}$ bronchogenic carcinoma; ${ }^{d}$ ischaemic heart disease during follow-up period

Table 4. Clinical features and paraclinical data of 29 control subjects investigated from 1967-1969

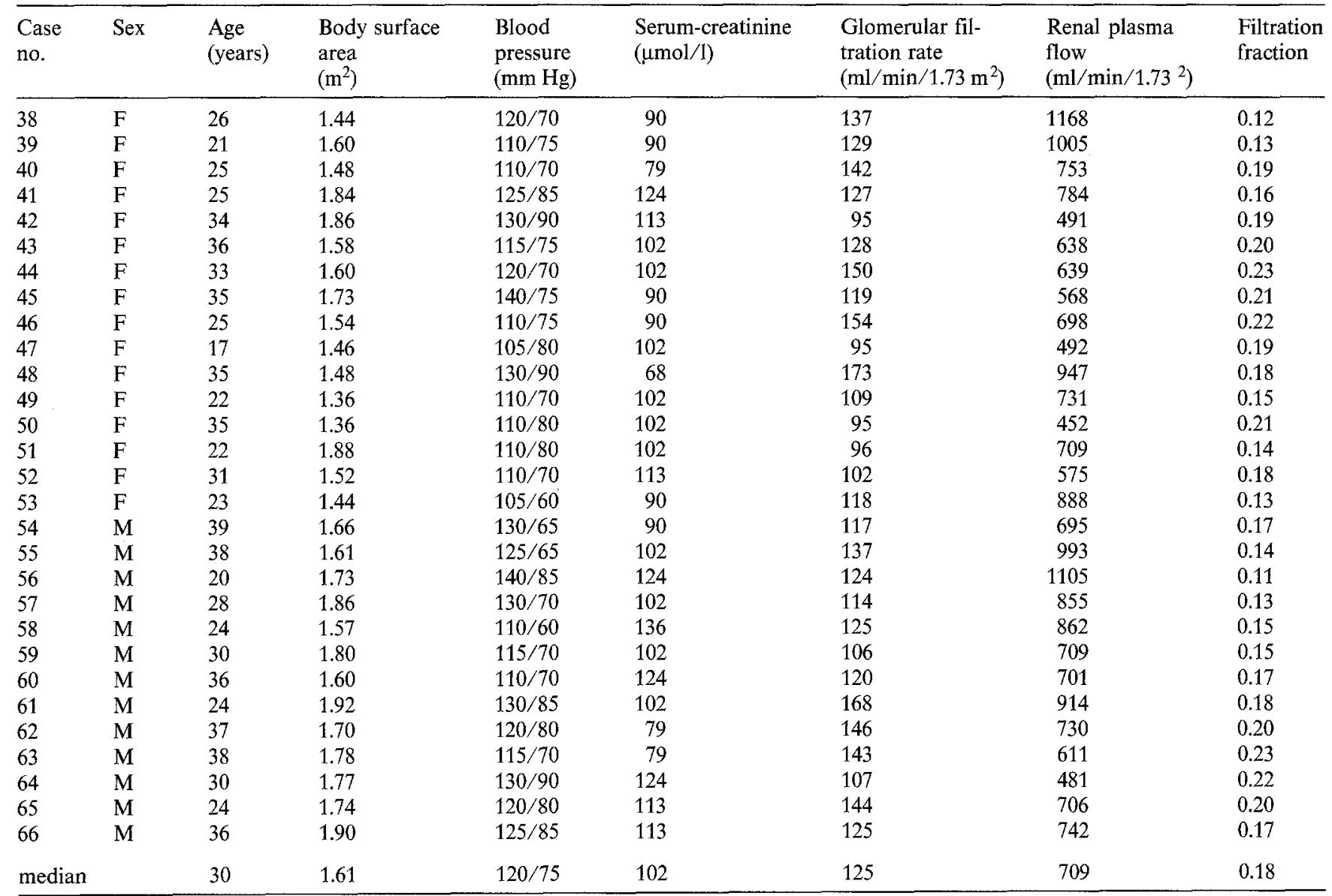

\section{Follow-up examination}

The 29 diabetic patients were divided into two groups according to their urinary excretion rates. In the 8 patients with elevated UAE the median value was $515(32-3234) \mu \mathrm{g} / \mathrm{min}$ and was clearly separated from the 21 diabetic patients with normal UAE. Seven out of 8 had values of UAE greater than $71 \mu \mathrm{g} / \mathrm{min}$. Both median blood pressure $(145 / 90 \mathrm{~mm} \mathrm{Hg}$ vs $120 / 80 \mathrm{~mm} \mathrm{Hg} ; p<0.02)$ and the frequency of prolif- erative retinopathy ( 7 out of 8 vs 2 out of $21 ; p=0.0001$ ) were significantly increased among the patients with abnormal UAE as compared to the group with normal UAE. Three out of the 29 diabetic patients (all with increased UAE) received antihypertensive treatment.

No significant correlation was found between $\mathrm{UAE}$ and initial GFR (Spearman rho $=0.095 ; p>0.05$ ) (Fig.1). The median initial GFR was 142(117-170) $\mathrm{ml} / \mathrm{min} / 1.73 \mathrm{~m}^{2}$ in the diabetic patients with increased UAE as compared to $147(102-193) \mathrm{ml} / \mathrm{min} / 1.73 \mathrm{~m}^{2}$ in 


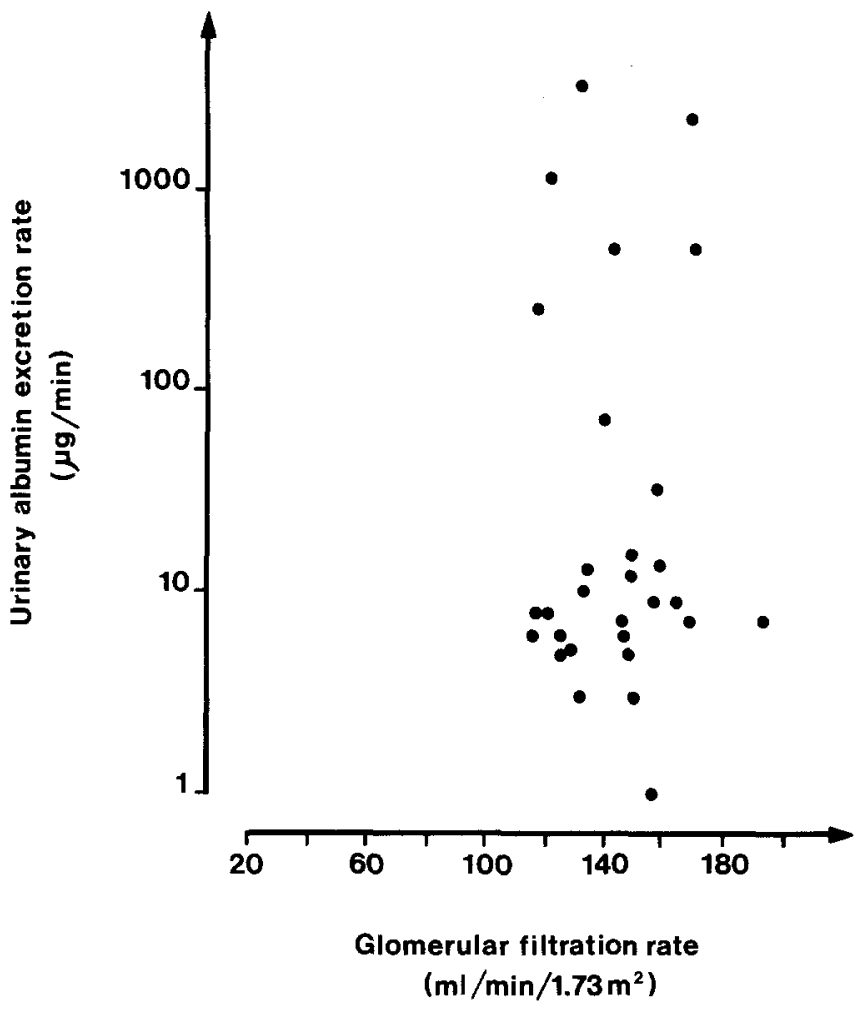

Fig. 1. Urinary albumin excretion rate (log scale) in 29 diabetic patients plotted against glomerular filtration rate at initial examination (Spearman $\mathrm{rho}=0.095 ; p>0.05$ )

the patients with normal UAE. Nor were there any significant relationships between increased UAE and the initially determined RPF or filtration fraction. However, UAE was negatively correlated with follow-up GFR as shown in Figure 2 (Spearman rho $=-0.536$; $p<0.01)$. GFR at follow-up was decreased in the group with abnormal UAE as compared to the diabetic patients with normal albumin excretion [85(32-128) vs $\left.126(88-165) \mathrm{ml} / \mathrm{min} / 1.73 \mathrm{~m}^{2} ; p<0.01\right]$. The diabetic patients with increased UAE had higher serum creatinine levels [107(91-211) $\mu \mathrm{mol} / 1$ vs $81(54-104) \mu \mathrm{mol} / 1 ; \quad p<0.01]$ and higher serum $\beta_{2}$-microglobulin levels $[186(147-476) \mathrm{nmol} / \mathrm{l}$ vs $120(93-158) \mathrm{nmol} / 1 ; p<0.01]$ as compared to patients with normal UAE. The groups were similar with respect to age, duration of diabetes, insulin dose, body surface area, blood glucose and $\mathrm{HbA}_{1 \mathrm{c}}$.

\section{Discussion}

Duration of disease is the major susceptibility factor for the development of diabetic retinopathy and nephropathy. Though most diabetic patients suffer from some structural and functional changes in the kidney glomeruli even early in the disease it still remains unexplained why only approximately one-third of the patients progress to diabetic nephropathy and renal failure [20].

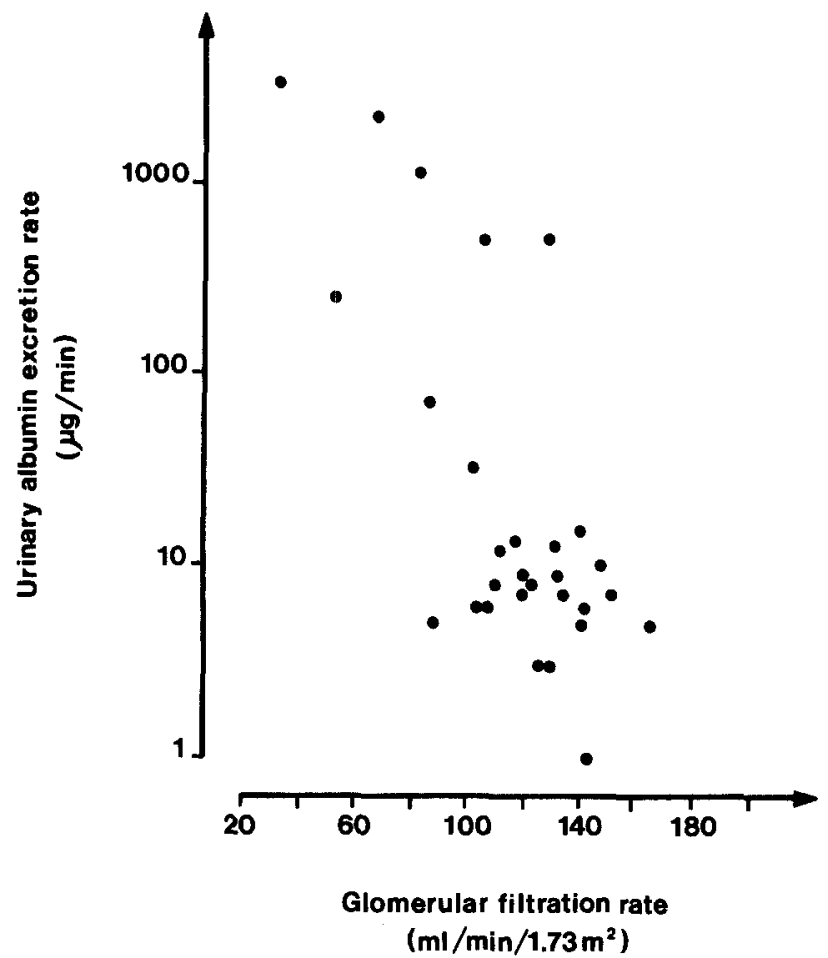

Fig. 2. Urinary albumin excretion rate (log scale) in 29 diabetic patients plotted against glomerular filtration rate at follow-up examination (Spearman rho $=-0.536 ; p<0.01$ )

Microalbuminuria strongly predicts diabetic nephropathy, the progression of which may be reduced by continuous subcutaneous infusion of insulin [21] and by early antihypertensive treatment $[22,23]$. However, once macroalbuminuria appears the fatal outcome is predictable $[20,24]$. Therefore, a crucial goal in prevention would be to demonstrate factors early during the disease which may indicate the development of renal failure in the individual patient.

Based on single-nephron micropuncture studies in experimental diabetic rats it has been supposed that glomerular hyperfiltration, resulting from concomitant elevations in glomerular flow and pressure, might be an early marker of subsequent renal damage [6-8]. Recent findings by Mogensen in Type 1 diabetic patients $[11,12]$ tends to support this hypothesis. In both latter clinical studies renal function was reinvestigated in, respectively, 24 and 12 male diabetic patients; a significant association was found between early glomerular hyperfiltration and development of late nephropathy. In our study no association was demonstrable between early elevated glomerular filtration rate (or increased filtration fraction) and late incipient or overt nephropathy. Nor were such associations found when males or female diabetic patients were analysed separately.

The reason for the different results found by Mogensen and the present study may be due to several factors. The diabetic patients in the studies by Mogensen had a mean age at diagnosis of 12 and 14 years, re- 
spectively, as compared to the mean age of 19 years in our study; and the initial mean duration of diabetes were 12 and 6 years as compared to 3 years in the present study. The mean follow-up periods were only 10 and 13 years in the studies by Mogensen in contrast to 19 years in the present study, and this longer follow-up period might have given rise to an increased frequency of patients with nephropathy. The short-term regulation of diabetes in the 3 studies may be different, although the mean blood glucose levels appear to be similar. The long-term quality of metabolic control of the diabetic patients in the 3 studies cannot be compared because of insufficient accumulation of data within the follow-up period. The determination of glycosylated haemoglobin was not a routine laboratory method at the initial examination and for several years thereafter. The methodology used for the GFR determinations was also different as Mogensen used iothalamate or inulin as filtration markers at the initial examination, while we used ${ }^{51}$ Chromium-EDTA or inulin with correction of the former. In the studies by Mogensen microalbuminuria were present in many of the diabetic patients even at the initial examination and from their studies it is, therefore, not possible to establish whether hyperfiltration per se may predict late renal failure. We did not have the possibility of measuring microalbuminuria at the initial examination in 1967.

The finding by Mogensen and Christensen [11] of a significantly higher blood pressure initially in the group of diabetic patients who subsequently developed nephropathy at follow-up could not be confirmed either by Mogensen [12] or in the present study. However, as might be expected, we found a higher blood pressure and an increased frequency of proliferative retinopathy at follow-up in the diabetic patients with increased urinary albumin excretion rates $[25,26]$.

Although experimental evidence suggest that increased GFR is linked to intrarenal hypertension and progressive renal damage, the verification of this hypothesis in human diabetes is probably difficult to establish. As several factors such as dietary protein-intake $[27,28]$, metabolic control of diabetes [29-31] and plasma levels of various endogenous hormones [32-34] are known reversibly to influence the level of GFR, future studies of GFR must be carried out prospectively with due consideration of these variables.

Acknowledgement. This work was supported by grants from the Danish Diabetes Association, from Northern Jutland County Medical Research Fund and Aalborg Stifts Julelotteri.

\section{References}

1. Stalder G, Schmid R (1959) Severe functional disorders of glomerular capillaries and renal hemodynamics in treated diabetes mellitus during childhood. Ann Paediat 193: 128-138

2. Ditzel J, Junker K (1972) Abnormal glomerular filtration rate, renal plasma flow and renal protein excretion in recent and short-term diabetes. Br Med J 2: 13-19

3. Mogensen CE (1972) Kidney function and glomerular permeability to macromolecules in juvenile diabetes. Dan Med Bull 19 [Suppl. 3]: 1-40

4. Brøchner-Mortensen J, Ditzel J, Mogensen CE, Rødbro P (1979) Microvascular permeability to albumin and glomerular filtration rate in diabetic and normal children. Diabetologia 16: 307-311

5. Christiansen JS, Gammelgaard J, Frandsen M, Parving H-H (1981) Increased kidney size, glomerular filtration rate and renal plasma flow in short-term insulin dependent diabetics. Diabetologia 20: 451-456

6. Mauer SB, Steffes MW, Brown DM (1981) The kidney in diabetes. Am J Med 70: 603-612

7. Parving $\mathrm{H}-\mathrm{H}$, Viberti GC, Keen $\mathrm{H}$, Christiansen JS, Lassen NA (1983) Hemodynamic factors in the genesis of diabetic microangiopathy. Metabolism 32: 943-949

8. Zazt R, Brenner BM (1986) Pathogenesis of diabetic microangiopathy. The hemodynamic view. Am J Med 80: 443-453

9. Hostetter TH, Rennke HG, Brenner BMl (1982) The case for intrarenal hypertension in the initiation and progression of diabetic and other glomerulopathies. Am J Med 72:375-380

10. Zazt R, Dunn BR, Meyer TW, Anderson S, Rennke HG, Brenner BM (1986) Prevention of diabetic glomerulopathy by pharmacological amelioration of glomerular capillary hypertension. J Clin Invest 77: 1925-1930

11. Mogensen CE, Christensen CK (1984) Predicting diabetic nephropathy in insulin-dependent patients. N Engl J Med 311: 89-93

12. Mogensen CE (1986) Early glomerular hyperfiltration in insulindependent diabetics and late nephropathy. Scand J Clin Lab Invest 46: 201-206

13. Aurell M, Ditzel J (1970) Renal clearance of ${ }^{51} \mathrm{Cr}$-EDTAcomplex: a comparison between continuous infusion and single injection techniques. In: Proceedings of the 7th International Congress on Clinical Chemistry, Vol 3. Karger, Basel New York, pp 405-413

14. Smith HW, Finckelstein N, Aliminosa L, Crawford B, Braber M (1945) Renal clearances of substituted hippuric acid derivatives and other aromatic acids in $\operatorname{dog}$ and man. $\mathbf{J}$ Clin Invest 24: 388-404

15. Ram MD, Evans K, Chisholm GD (1967) Measurements of effective renal plasma-flow by the clearance of ${ }^{125} \mathrm{I}$-Hippuran. Lancet II: $645-646$

16. Brøchner-Mortensen J (1978) Routine methods and their reliability for assessment of glomerular filtration rate in adults. Dan Med Bull 25: 181-202

17. Mancini G, Carbonara AO, Heremans JF (1965) Immunochemical quantitation of antigens by single radial immunodiffusion. Immunochemistry 2: 235-239

18. Mogensen CE, Chachati A, Christensen CK, Close CF, Deckert T, Hommel E, Kastrup J, Lefebvre P, Mathiesen ER, Feldt-Rasmussen B, Schmitz A, Viberti GC (1985-1986) Microalbuminuria. An early marker of renal involvement in diabetes. Uremia Investigation 9: 85-96

19. Jeppsson J-O, Jerntorp P, Sundkvist G, Englund H, Nylund V (1986) Measurement of hemoglobin $A_{1 c}$ by a new liquid-chromatographic assay: methodology, clinical utility, and relation to glucose tolerance evaluated. Clin Chem 32: 1867-1872

20. Andersen AR, Christiansen JS, Andersen JK, Kreiner S, Deckert $\mathrm{T}$ (1983) Diabetic nephropathy in type I (insulin dependent) diabetes: an epidemiological study. Diabetologia 25: 496-501

21. Feldt-Rasmussen B, Mathiesen ER, Deckert T (1986) Effect of two years of strict metabolic control on progression of incipient nephropathy in insulin dependent diabetes. Lancet II: $1300-1304$

22. Mogensen CE (1982) Long term anti-hypertensive treatment inhibiting progression of diabetic nephropathy. $\mathrm{Br}$ Med $\mathrm{J} \mathrm{285:}$ 685-688

23. Parving H-H, Andersen AR, Smidt UM, Svendsen PAa (1983) 
Early aggressive antihypertensive treatment reduces rate of decline in kidney function in diabetic nephropathy. Lancet I: 1175-1179

24. Viberti GC, Bilous RW, Mackintosh D, Bending JJ, Keen $\mathrm{H}$ (1983) Long term correction of hyperglycaemia and progression of renal failure in insulin dependent diabetes. Br Med J 286: 598-602

25. Vigstrup J, Mogensen CE (1985) Proliferative retinopathy: at risk patients identified by early detection of microalbuminuria. Acta Ophthalmol (Copenh) 63: 530-534

26. Parving H-H, Hommel E, Mathiesen E, Skøtt P, Edsberg B, Bahnsen M, Lauritzen M, Hougaard P, Lauritzen E (1988) Prevalence of microalbuminuria, arterial hypertension, retinopathy and neuropathy in patients with insulin dependent diabetes. $\mathrm{Br}$ Med J 296: 156-160

27. Sølling K, Christensen CK, Sølling J, Christiansen JS, Mogensen CE (1986) Effect on renal haemodynamics, glomerular filtration rate and albumin excretion of high oral protein load. Scand $\mathrm{J}$ Clin Lab Invest 46: 351-357

28. Wiseman MJ, Bognelli E, Dodds R, Keen H, Viberti GC (1987) Changes in renal function in response to protein restricted diet in Type 1 (insulin-dependent) diabetic patients. Diabetologia 30 : 154-159

29. Parving H-H, Noer I, Deckert T, Evrin P-E, Nielsen SL, Lyngsøe J, Mogensen CE, Roth M, Svendsen PAa, Trap-Jensen J, Lassen NA (1976) The effect of metabolic regulation on microvascular permeability to small and large molecules in short-term juvenile diabetics. Diabetologia 12: 161-166
30. Christiansen JS, Gammelgaard J, Tronier B, Svendsen PAa, Parving H-H (1982) Kidney function and size in diabetics before and during initial insulin treatment. Kidney Int 21: 683-688

31. Wiseman MJ, Saunders AJ, Keen H, Viberti GC (1985) Effect of blood glucose control on increased glomerular filtration rate and kidney size in insulin-dependent diabetes. N Engl J Med 312: 617-621

32. Parving H-H, Christiansen JS, Noer I, Tronier B, Mogensen CE (1980) The effect of glucagon infusion on kidney function in short-term insulin-dependent juvenile diabetics. Diabetologia 19: 350-354

33. Christiansen JS, Gammelgaard J, Ørskov H, Andersen AR, Telmer S, Parving H-H (1981) Kidney function and size in normal subjects before and during growth hormone administration for one week. Eur J Clin Invest 11: 487-490

34. Kon V, Ichikawa L (1985) Hormonal regulation of glomerular filtration. Ann Rev Med 36: 515-531

Received: 30 March 1988

and in revised form: 25 July 1988

Dr. J. Ditzel

Section of Endocrinology

Department of Medicine

Aalborg Hospital

P.O. Box 561

DK-9100 Aalborg

Denmark 